\title{
A digitális tananyagfejlesztés speciális szempontjai
}

\author{
Vetési Erika
}

Eötvös Loránd Tudományegyetem Tanitó- és Óvóképző Kar Digitális Pedagógiai Tanszék

\begin{abstract}
Absztrakt
2020 tavaszán a világjárvány által kiváltott nem várt események hatására a digitális transzformáció az oktatásban új lendületet kapott. A digitális térben sok olyan lehetőség nyílt a tanulók digitális tanrendjének bevezetése során, amelyre korábban nem volt példa. Ez az írás abban kíván segítséget nyújtani, hogy a jövőbeni hasonló helyzet esetén milyen speciális szempontokat kell figyelembe venni a digitális tananyagok fejlesztése során. Éppen ezért az alább tárgyalt szempontok vizsgálata sohasem volt annyira aktuális, mint most.
\end{abstract}

Kulcsszavak: digitális transzformáció, digitális oktatás, digitális oktatási környezet, 21. századi tanulás, digitális tananyag

\section{Bevezetés}

A 2020 tavaszán a közoktatásban elrendelt digitális tanrend, valamint a felsőoktatási szférában bevezetett távolléti oktatás nem várt gyorsító erőként jelentkezett a digitális transzformáció folyamatában. Megfigyelhettük, hogy a digitális tartalmak előállításának és megosztásának számtalan formája hogyan igyekezett segíteni a pedagógusok munkáját. A digitális térben sohasem látott mértékben jelentek meg a segítő szándékú weboldalakról letölthető gyűjtemények, a különböző közösségimédia-felületek csoportjain belül, többnyire ingyenesen elérhető, ajánlott oldalak, applikációk, oktatási piaci termékek. A digitális oktatási piac fellendülését a váratlan események következményeinek tekinthetjük. Azonban az is igaz, hogy a kínálatban nagyon különböző színvonalú produktumokat találtunk. A felsorolt események miatt a digitális tananyagfejlesztés speciális szempontjainak vizsgálata sohasem volt annyira aktuális, mint most. A bőség zavarában azonnal megfogalmazódnak bennünk az első kérdések: Hogyan tájékozódjunk a sokféle információ között? Hogyan válasszunk, adott esetben hogyan készítsünk minőségi digitális tananyagokat? Ez az írás bemutatja, hogy a digitálistananyag-fejlesztés során pedagógiai szempontból milyen jelenségekre kell különös figyelmet fordítanunk. 


\section{Digitális tananyagok}

Mielőtt a digitális tananyagfejlesztés titkait kutatnánk, érdemes meghatároznunk, hogy mit tekintünk digitális tananyagnak. A laikus pedagógiai nézeteket vallók digitális tananyagként értelmezik a tankönyvek digitalizált oldalait, változatait is, a fellelhető sok-sok linkgyűjteményt, az elérhető, különböző témákban készült mozgóképes médiatartalmakat, a mások által készített és megosztott, de nem feltétlenül ellenőrzött feladatokat, feladatbankokat, ha azok a pedagógiai munkájukban segítségként alkalmazhatók. A tanulmány őket is igyekszik segíteni, a digitális taneszközök típusain belül a digitális tananyag és a digitális feladatkészítő és gyakorló rendszer fogalmának megismertetésével. A fogalmak tisztázásában a Digitális Taneszköz Minősítési Bizottság útmutatásaira támaszkodunk. Meglehetősen nehéz különbséget tenni a két fogalom között. A megkülönböztetésben a tantervhez kapcsolódás foka segíthet. Mindkét kategória jelen van a mindennapi oktatási gyakorlatunkban.

A fenti előzmények alapján megfogalmazhatjuk, a digitális tananyag olyan oktatási anyag, mely pedagógiai elvek alapján az informatika lehetőségeit az oktatási célok mentén kihasználva épül fel, amely állhat a digitális tananyagegység elemeiből, de önálló, tartalmi, módszertani szempontból zárt egészet is alkothat. Alapvető célja egy adott kompetencia kialakítása, fejlesztése. Egy vagy több tantervhez illeszkedhet, és minta-tanmenetet vagy oktatási javaslatokat tartalmazó leírás kapcsolódhat hozzá. Terjedelmi keretei szerint lefedhet egy évfolyamban egy tantárgyat, egy epochát vagy projektet, egy kultúrkör számára egy tantárgyat vagy tananyagegységet (DTMB, 2012).

A digitális feladatkészítő és gyakorló környezeten olyan, számunkra kidolgozott offline és online egyaránt elérhető és megjeleníthető szerzői keretrendszert értünk, amely a korszerű pedagógiai elveknek megfelelő feladatok és tesztek egyszerủ létrehozását támogatja. A digitális feladatkészítő és gyakorló környezet nem kapcsolódik tantervhez, felhasználási lehetőségeit a kapcsolódó tudásforrás és feladatbank tantervi háttere szabja meg (DTMB, 2012).

A pedagógiai gyakorlatunkban e két taneszköztípussal találkozunk legygyakrabban. A szabad tartalomlétrehozás és tartalommegosztás korában többféle lektorált és nem lektorált lehetőség közül választhatunk. A nem lektorált digitális feladatkészítő és gyakorló környezetek használatánál óriási jelentőségű a feladatok felhasználásánál az udvarias kételkedés, hiszen nem tudhatjuk, a tartalom előállítója és megosztója milyen pedagógiai ismeretekkel rendelkezik, mennyire biztos és adekvát ismeretek alapján készült a felhasználásra kínált feladat (Vetési, 2019).

A digitálistananyag-fejlesztés egyik legfontosabb szempontja, hogy az alkotók a pedagógián belül milyen mértékben képesek megfelelni a didaktikai elvárásoknak, milyen céllal, milyen színvonalú munkát képesek végezni. A lektoráltság, minősítettség többek között ennek a várhatóan magas színvo- 
nalú szakmai munkának az elismerése. Az is igaz azonban, hogy a tartalomelőállítás szabadsága hozza létre azt a sokszínűséget, melynek üdítő hatása lehet az oktatásinformatikai piac szereplőire.

\section{A digitális világ}

Azok a piaci szereplők, akik napjainkban a digitális térben igyekeznek a maguk digitális oktatással kapcsolatos célközönségét megtalálni, nincsenek könnyü helyzetben. A digitális tananyagok elérésnek fizikai adathordozókra vonatkozó evolúciója során megfigyelhettük, hogy az követte az általános trendet. Az első CD-ROM-ok, pendrive-ok után hamarosan a weboldalakon elérhető gyűjtemények váltak általánossá. A nemzetközi helyzet megfigyelésekor pedig azt tapasztaljuk, hogy a digitális tananyagok köré további osztályfelügyeleti funkciók ellátására is képes keretrendszerek épülnek, valamint elengedhetetlennek tűnik az ezekhez tartozó mobilapplikációk létrehozása is.

A jövőben egész biztosan változás várható a szülő-gyermek-iskola kommunikációs lehetőségeiben, szokásaiban. Ebben a kommunikációban a digitális tananyagokhoz való hozzáférés biztosítása olyan fejlesztési szemponttá válik, amelyet nagyon alaposan át kell gondolni. Ideális esetben a tanuló azonosítása egykapus rendszerben történik, vagyis a tanulónak iskolai feladatainak megoldásához egy iskolai azonosítót kell használnia. Hazánkban azonban a gyerekek sokféle felületen, sokféle azonosítóval érik el a nekik szánt digitális tartalmakat. Ebből a szempontból egészen bizonyos, hogy egyre szükségessebbé válik a tanulók adatvédelmi szabályozásához kapcsolódó, az oktatást érintő ajánlások kidolgozása.

A digitális tananyagokhoz való hozzáférés másik aspektusa az eszközellátottság. A fejlesztéseknek olyan irányba kell haladniuk, hogy a már ismert digitális egyenlőtlenségek ellenére a tanulók minél szélesebb körben bevonhassák a saját tanulási folyamataikba a digitális oktatás által kínált lehetőségeket. Ezzel kapcsoltban Kiss (2007) az évszázad elején még optimista és pesszimista előrejelzéseket fogalmazott meg. Azt írja tanulmányában, hogy jó esetben a hagyományos társadalmi egyenlőtlenségek csökkenéséhez vezet az infokommunikációs eszközök használta. Borúlátó jóslata szerint azonban mindezek növelik a meglévő egyenlőtlenségeket. Fehérvári (2017) tíz évvel később azt írja, hogy ez egyértelműen így történik. Az oktatási egyenlőtlenségekre különösen igaz, hogy a digitális egyenlőtlenségek a már meglévő társadalmi egyenlőtlenségekhez adódnak hozzá.

A digitális tananyagok fejlesztése során olyan három fő szempont rajzolódik ki egyértelmüen, melyeket a digitális világban való változások idéztek elő. A jövő fejlesztőinek döntéseket kell hozniuk, a digitális tananyagok fizikai adathordozóira vonatkozóan, irányokat kell megjelölniük a hozzáférés adatvédelmi aspektusában, valamint figyelembe kell venniük az eszközellátottsági mintázatokat is. 


\section{A digitális oktatási környezet}

A jelen digitális oktatási környezetére egyszerre igaz a hiánygazdálkodás és a pazarlás, hasonlóan ahhoz, amit a kilencvenes években hazánk egészségügyi rendszerével kapcsolatban tapasztalhattunk. Sokszor a legalapvetőbb taneszközökre sincs megfelelő forrás, miközben a különböző pályázatokon elnyert tanítást és tanulást egyaránt segítő, igen jó minőségű technikai eszközök a kicsomagolásig sem jutnak el. Ennek oka leggyakrabban az eszközhöz tartozó képzések elmaradása. Ebben a helyzetben a pedagógus továbbképzési rendszere átgondolásra vár, azzal együtt, hogy a digitális tananyagok fejlesztési folyamataiban is tudatosan kellene a pedagógusok bevonására törekedni.

Ebben a környezetben a tanulók, valamint a pedagógusok között is számítani kell Prievara és Nádori (2018) által digitális ellenállásnak nevezett jelenségre. A szerzők úgy fogalmaznak, hogy fel kell készülnünk a digitális transzformáció során azon tanulók szabotáló akcióira, akik egyébként kiválóan boldogulnak a közösségi hálózatok korában, de iskolai környezetben egyértelműen elutasítóak a digitális technológia használatával kapcsolatban feladatmegoldásaik során. A szerzők szerint elkerülhető a jelenség, ha a kötelező jelleget felváltja a lehetőség biztosítása.

Megoldást jelenthet az is, ha a digitális tananyagok fejlesztési folyamataiba a tanulókat is bevonjuk. Lénárd és Szitányi (2018) kutatásukban arra a következtetésre jutottak, hogy a tanulók rendelkeznek olyan tudáselemekkel, tapasztalati bázissal, melyeket a tananyagfejlesztés folyamatában fel lehet használni.

A jövőben a digitális oktatási környezet szereplőinek törekedni kell a közös célok kialakítására. Ehhez elengedhetetlen, hogy a digitális-tananyagfejlesztés során a fejlesztők egyaránt figyelembe vegyék és érzékenyen reagáljanak a tanulói és tanári, tanítói tapasztalatokra, a köreikben megfigyelhető jelenségekre, a folyamatosan változó szükségleteikre.

\section{Életkori sajátosságok}

A digitálistananyag-fejlesztések kiemelten fontos szempontja az életkori sajátosságok figyelembevétele. Ezek meghatározása több módon is történhet. A tanulmány egyrészt a korosztályhoz tartozó nevezéktan áttekintésével igyekszik feltárni a mai gyermekekre jellemző tulajdonságokat, másrészt a témával kapcsolatban kutatók megfigyeléseit, tapasztalatait gyűjti össze.

A 21. századi gyerekekre nagyon sok külső tényező hat, melyek közül a digitalizációnak döntő szerepe van. Az a digitális környezet, amely körülveszi őket, áthatja az iskolai és iskolán kívüli életüket egyaránt. A 6-10 éves korosztályba tartozó gyerekek egyre gyakrabban találkoznak iskolai szituációkban is digitális eszközhasználati feladatokkal. Életkori sajátosságaik nem eltűnnek, hanem kiegészülnek a digitális tananyagok fejlesztése során alkalmazható, különösen fontos elemekkel. 
A digitális transzformáció hatással van az életkori sajátosságokra, a digitális tanulási környezetben a tanulási szükségletekre is. Az információs és kommunikációs technológiai eszközök életünkre gyakorolt hatását a kutatók a gyerekek és a felnőttek esetében különbözőnek látják. A szakirodalomban több kétpólusú szembenállást feltételező megnevezéssel is illetik a korosztályokat. A nevezéktan sokféleségének többek között alapjául szolgálnak például a digitális eszközök, a világháló használatbeli, vagy a digitális világhoz való attitűdbeli különbségek. A jelenséget leíró három leggyakoribb fogalom az X-, Y-, Z-, $\alpha$-generáció (Howe \& Strauss, 1992), a netgeneráció (Tapscott, 2009) és a digitális bennszülöttek és digitális bevándorlók elnevezések (Prensky, 2001).

William Strauss és Neil Howe (1992) Generations címü könyvükben az amerikai történelmet egymást követő generációk történelmeként mutatják be. Felosztásukban megkülönböztetnek veteránokat, akik a múlt század húszas, harmincas éveiben születtek. A baby boomereket az X-, Y-, Z-, illetve a-generáció követi aszerint, hogy a különböző kategóriákba tartozók mikor születtek, valamint születési dátumuk szerint milyen digitális környezet vette őket körül (Howe \& Strauss, 1992).

Tapscott (2009) szerint a netgenerációba tartozó gyermekek internethasználata egészen új távlatokat nyit, hiszen új lehetőségeket, aktivitást biztosít számukra a korábbi passzivitásra alapuló televíziózással szemben. Olyan pozitív hatásokról ír a szerző, amelyeket a munkaerőpiac, de az oktatás sem hagyhat figyelmen kívül. Tapscott szerint a netgeneráció tagjai többek között kíváncsibbak, önállóbbak, öntudatosabbak, semmit sem fogadnak el kritikátlanul (Tapscott, 2009).

A digitális bennszülöttek és ezzel együtt a digitális bevándorlók megnevezések Marc Prenskytől (2001) származnak. Megfigyelése során megállapította, hogy a fiatalok, a digitális bennszülöttek anyanyelvi szinten beszélik a számítógépek, videojátékok és az internet digitális nyelvét. Míg az idősebbek, a digitális bevándorlók bizonyos mértékig "akcentussal” teszik mindezt. A megkülönböztetés alapja, hogy míg a digitális bennszülöttek beleszülettek a digitális korba, vívmányainak használatába, addig a digitális bevándorlók most tanulják ezt a nyelvet. Lassan, lépésről lépésre, egymás után, egyedül, és mindenekfelett, komolyan tanulják meg a digitális eszközök használatát. Ebből adódik az akcentusuk. Prensky részletesen kitér arra, hogy a digitális bennszülöttek szükségletei milyen természetűek.

Véleménye szerint a digitális bennszülötteknek

- azonnali megerősítésre,

- gyakori jutalmazásra,

- gyors információelérésre van szükségük,

- ők azok, akik az ábrákat, képeket előnyben részesítik a szöveggel szemben,

- szükségük van arra is, hogy a tanulás a játék, a szórakozás között harmónia legyen,

- szeretnek egyszerre több mindennel foglalkozni párhuzamosan, 
- szabad teret igényelnek a véletlen elérésnek,

- hatékonyabbak, ha hálózatban müködhetnek (Prensky, 2001).

A hazai nevezéktanban Fehér és Hornyák (2011) tovább bontották a digitális bennszülöttek csoportját. Megkülönböztetnek új hódítókat, csipegetőket és leszakadókat, valamint ezeket az alcsoportokat is tovább bontották még kisebb csoportokra. Megközelítésükben a digitális bevándorlókat a hódítók/felfedezők, a derékhad és a kívül rekedtek alkotják (Fehér \& Hornyák, 2011).

Z. Karvalics Lászlótól (2013) származik a digitális bennszülöttek és digitális bevándorlók megnevezések által szakadékot jelentő szavak feloldására alkalmas, digitális beavatottak kifejezés. A beavatott kifejezésnek mind a magyar, mind az angol változatában van a textilekhez füződő jelentése. A textilek beavatása nem más, mint a textilneműk festékkel, impregnáló anyagokkal való átitatása a későbbi felhasználás előtt, valamilyen tulajdonságot kialakító vagy megerősítő szándékkal. Z. Karvalics László szerint ebben az értelmezésben a textil a fiatal nemzedék, a festékanyag a digitális kultúra. Így a korosztály tagjai különböző mértékben itatódnak át a későbbi felhasználás céljából (Z. Karvalics, 2013).

Buda Andrástól (2017) származik a digitális nomádok és digitális telepesek elnevezés. Felosztásában egyfajta evolúciós szemlélet fedezhető fel. A digitális remetéktöl a digitális honfoglalókig több társadalmi csoportot nevez meg a csoportba tartozók digitális kompetenciájának fejlettsége alapján (Buda, 2017).

A generációs különbségek megfigyeléséből született elnevezések után kutatóink tapasztalataiból összeállított válogatás következik.

Az életkori sajátosságok változásának bemutatását gazdagítják Lénárd András (2015) gondolatai. Tanulmányában a digitális kor gyermekeivel kapcsolatban megállapítja, hogy a mai gyerekek képesek párhuzamosan vagy párhuzamosan tűnő módon feldolgozni az eltérő természetű információkat a hagyományos lineáris modellek helyett. A gyerekekkel kapcsolatban sokszor emlegetett multitasking, a feladatok párhuzamos egyidejű végzése, szerinte inkább gyors szekvenciális adatfeldolgozást jelent. A gyerekek gondolkodásában azonban léteznek linkszerű momentumok. Ezek a linkek, többek között, lehetnek gondolatelemek, emléknyomok vagy korábbi tapasztalatok. A legfőbb probléma, hogy a külső szemlélő által követhetetlenek azok a folyamatok, ahogyan ezekből a linkekből álló utak felépülnek, sőt nagyon egyediek, ezért nehéz megítélni, hogy csapongásról vagy többszörös átkapcsolódásról van-e szó. A szerző tapasztalatai szerint ezek a gyerek gondolkodásában lévő ugrópontok gyakran hasznosíthatók a velük való foglalkozás során. Megemlíti, hogy a digitális kor gyermekei ingerfalók, az információéhséggel együttjáró türelmetlenség is jellemzi őket. Ezek mellett a digitális környezetben való hálózatosodás, a hálózatban működés igénye erősen jelen van a mai gyerekek körében. A pedagógusok tekintélye, véleménye szerint, ebben a környezetben sem csökken, ha utakat, módokat mutatnak meg a tanulóknak. Ugyanis bármennyire tűnik is úgy, hogy ez a generáció a minden- 
napi eszközhasználatban járatos vagy járatosabb a pedagógusoknál, a digitális kompetenciájuk koránt sem olyan fejlett, mint azt gondolnánk, ugyanis a digitális kompetencia nem egyenlő a digitális eszközhasználattal (a felsőoktatás egy szegletére nézve lásd M. Pintér, 2019). Ezt megerősíti a szakirodalom is, hiszen Heinz Mandl (1995) szerint a digitális kompetenciának része az eszközhasználaton, a technikai kompetencián túl az információk közötti eligazodás, a szociális és kommunikációs, az egyéni és demokratikus orientáció kompetenciája is (Mandl, Gruber, \& Renkl, 1995; Lénárd 2015, 2017).

Wagner Éva (2015) tanulmányában összefoglalja azokat a különbségeket, amelyeket tapasztalt. A mai gyerekek nagyon nehezen tudnak figyelni, egyre többen vannak köztük olyanok, akik nehezen fejezik ki magukat, sokaknak rossz a mozgáskoordinációja, nehéz velük lépcsőn közlekedni, a járásban hamar elfáradnak, nehezebb velük megfelelően haladni a tanulásban. A családok mindennapjait, napi rutinját gyökeresen átalakította a digitális média és a fogyasztói társadalom. A családok mindennapjainak ugyan része a mese, a beszélgetés, de az erre fordított idő lényeges kevesebb, mint korábban. A 21. századi gyerekek tanulása rövid 2-7 perces idő egységekben zajlik. A tanulás fontos elemei az önirányítottság, az egyéni érdeklődés azonnali kielégítése, az azonnali visszajelzés, a hibázás, tévesztés szabad kijavítása. A tanulás során a megismerés, a látvány egészleges, nem balról jobbra, fentről lefelé történik, a figyelem sok egyidejü inger között oszlik meg, amit a mai gyerekek igényelnek is. Ebben a környezetben a gyerekek sokkal kevesebbet beszélnek, az információszerzésük iránya a vizuális közlések felé tolódik, egyre kisebb hangsúly van a verbális közléseken (Wagner, 2015).

Nemcsak a tanulók jellemzői, szükségletei változtak meg, hanem a tanuláshoz használt taneszközök is. Papp-Danka Adrienn (2013) tanulmányában arról ír, hogy az offline tankönyvi és papír-ceruza eszközökhöz képest egyértelmủen a számítógép lett a tanuláshoz használt eszköz. Tanulmányában azzal indokolta ezt a megállapítását, hogy a tanulók az iskolában és az otthoni tanuláshoz is sok olyan feladatot kapnak, amelyek elvégzéséhez kell a számítógép, de az is lehetséges, hogy a számítógép mintegy „háttérzajként” állandó eleme a papíralapú tanulásnak.

Éppen ezért nem mindegy, hogy a digitális taneszközök széles skáláján belül mit kínálunk a digitális kor gyermekeinek tanuláshoz. A digitális tananyagfejlesztés során az életkori sajátosságok figyelembevétele kiemelt fontosságú. A szakirodalom a dichotóm nevezéktanon túl sokféle megközelítésben tárja fel a megváltozott életkori sajátosságokat, melyre a fejlesztések során mindenképpen reflektálnunk kell.

\section{Összegzés}

A digitális tananyagfejlesztések során több tényező figyelembevételére törekszünk, melyek közül jelen tanulmány a pedagógiai megközelítést vette alapul. A digitális világban történő folyamatos változások közül a fizikai adathor- 
dozók evoluciójának mentén, a tananyagokhoz való hozzáférés tekintetében a tanulók azonosítása, valamint az eszközellátottság dimenziója volt segítségünkre vizsgálódásom során. A digitális oktatási környezet szereplőinek, a tanulóknak és pedagógusoknak a bevonása a digitális tananyagok fejlesztésébe olyan kiváló lehetőség, melyre már van példa a hazai gyakorlatban. Az életkori sajátosságokhoz kapcsolódó nevezéktani gyüjtemény, illetve kutatóink tapasztalatainak összegzése segíthet megérteni a digitális tananyagok fejlesztésének legfontosabb célközönségét, a ránk bízott tanulókat.

\section{Irodalom}

Buda, A. (2017). IKT és oktatás. Együtt vagy egymás mellett. Belvedere Meridionale Kiadó. https://doi.org/10.14232/belvbook.2017.58528

DTMB. (2012. május 9.). http://www.nefmi.gov.hu/kozoktatas/oknt-bizottsagai/ digitalistananyag/digitalis-tananyag

Fehér, P. \& Hornyák, J. (2011). 8 óra pihenés, 8 óra szórakozás, avagy a Netgeneráció 2010 kutatás tapasztalatai. Videotorium. https://bit.ly/2CFRfWe (2019.03.26.)

Fehérvári, A. (2017). Digitális esélyegyenlőtlenségek Magyarországon. Educatio, 26(2), 157-168. https://doi.org/10.1556/2063.26.2017.2.1

Howe, N. \& Strauss, W. (1992). Generations. The History of America's Future, 1584 to 2069. Harper Perennial.

Kiss, M. (2007). A digitális esélyegyenlőség helyzete Magyarországon. Információs Társadalom, 7(3), 83-101.

Lénárd, A. (2015). A digitális kor gyermekei. Gyermeknevelés Tudományos Folyóirat, 3(1), 74-83. https://doi.org/10.31074/gyntf.2015.1.74.83

Lénárd, A. (2017). Digitális Témahét felkészítő webináriumi sorozat. A digitális kor gyermekei. https://www.youtube.com/watch?v=JKe0RLtyCCg (2019. 03.09.)

Lénárd, A. \& Szitányi, J. (2018). Methodological Questions of Digital Teaching Material Development Made in the Subject of Mathematics. Teaching Mathematics and Computer Science, 16(1) 25-41. https://doi.org/10.5485/TMCS.2018.0441

Mandl, H., Gruber, H., \& Renkl, A. (1995). Auf dem Weg ins Informationszeitalter? Was Wirtschaft, Politik und Öffentlichkeit bewegt, was auf die Gesellschaft und auf die Bildung zukommt. Research report No. 54.

M. Pintér, T. (2019). Digitális kompetenciák a felsőoktatásban. Modern Nyelvoktatás, 25(1), 47-59.

Papp-Danka, A. (2013). Digitális bennszülött vagy digitális állampolgár? - Tanulók a digitális világban. In Ollé, J. (Ed.), Digitális állampolgárság az információs társadalomban (pp. 33-41). Budapest.

Prensky, M. (2001). Digital Natives, Digital Immigrants. Part 1-2. On the Horizon NBC University Press, 9(5), 1-6. https://doi.org/10.1108/10748120110424816

Prievara, T., \& Nádori, G. (2018). A 21. századi iskola. Enabler Kft. 
Vetési, E. (2019). Digitális oktatási környezet. In Lénárd, A. (Ed.), A digitális oktatás útjain: Okos Doboz módszertani kézikönyv (pp. 15-21). Wizper Kft.

Wágner Éva (2015). Mai gyerek és az iskola. Gyermeknevelés, 3(1), 54-59. 


\section{Vetési, E.}

\section{Special aspects in developing digital learning materials}

In the spring of 2020, the digital transformation in education received a new impetus as a result of unexpected events. In the digital space, many opportunities have opened up for the introduction of digital syllabus for students that have not been seen before. This essay is intended to help you consider what special considerations should be taken into account when developing digital learning materials should a similar situation arise in the future. For this reason, it can be said that the examination of these aspects has never been as actual as it is now.

Keywords: digital transformation, digital education, digital educational environment, 21st century learning, digital syllabus

Vetési Erika: https://orcid.org/0000-0002-4380-5576 